\title{
BIOLOGICAL CONTAMINATION OF BARLEY AND CARROTS BY PATHOGENS IN SOIL FERTILISED WITH ANTHROPOGENIC NUTRIENTS
}

\author{
Hanna Launokorpi \\ Marjukka Dyer \\ Eeva-Liisa Viskari \\ TAMK University of Applied Sciences, Tampere, Finland
}

\begin{abstract}
The aim of this study was to find out if the use of septic tank sludge, urine and composted faeces as fertilizer for barley and carrot crops would pose a health risk due to pathogen transfer.

This study was accomplished as a greenhouse experiment in the premises of the TAMK University of Applied Sciences, Tampere. The study concentrated on the qualitative detection of Salmonella and a quantitative detection of coliform bacteria in the growing medium - and more importantly, in the plant products. Methods used were based on instructions given on the compact salmonella (SL) detection plates and the Compact coliform (CF) detection plates with a modified method of standards SFS 3950 and SFS 4447. The results were compared among others to the European Commission regulation 2073/2005 on microbiological criteria for foodstuff.
\end{abstract}

Salmonella was absent in the fertilizers, and thus its presence would be impossible in the plant products. Coliform bacteria were initially detected in the growing medium, but generally the amount decreased significantly within time. At the end of the experiment barley grains from the first urine duplicate and first composted faeces duplicate were totally free of coliform bacteria. Also, the amount of coliform bacteria in barley grains of other treatments was acceptable in hygienic terms, being less than $1 \mathrm{cfu} / \mathrm{g}$. The amount of coliform bacteria in carrots grown in commercial fertilizer and composted faeces treatments were within the satisfactory limits. The small size of carrots from urine and septic tank sludge treatments did not allow complete handling, nevertheless, the amount of colony forming units was considered to be within the acceptable limit of $100-1000 \mathrm{cfu} / \mathrm{g}$. Results from this study indicate that the use of composted excreta and source separated human urine as fertilizer is not posing a health risk in terms of coliform bacteria. More thorough research, however, is needed in order to define the risk of other disease causing microbes, like enterococci and viruses.

\section{KEYWORDS}

Salmonella; Coliform bacteria; Barley; Carrot; Septic tank sludge; STS; Urine; Composted faeces. 


\section{INTRODUCTION}

On average, an adult person annually produces approximately $500 \mathrm{~kg}$ of urine and $50 \mathrm{~kg}$ of faeces. Of that, $5.7 \mathrm{~kg}$ is nitrogen, $0.6 \mathrm{~kg}$ is phosphorus and $1.2 \mathrm{~kg}$ is potassium. There is a considerable difference between both the nutrient and pathogen content of different excreta. Urine contains approximately $90 \%$ of $\mathrm{N}, 50-65 \%$ of $\mathrm{P}$ and $50-80 \%$ of $\mathrm{K}$ that is excreted by humans. [1] In addition, urine contains very little heavy metals and it is considered almost pathogen free, while faeces contain several pathogens. [2] In the past, human excreta was widely used as a fertilizer in fields due to its nutrient-rich content. Today, its usage, apart from countries for instance in East Asia, is more uncommon. [3]

The main reason for excreta use decline is the health risk it can pose to the environment, especially to the people working in the fields and those consuming the food products. [4] In most cases, however, the most significant health risks are a result of improper handling during the different phases - the excreta used is untreated, the crops are eaten raw and unwashed, and the levels of personal hygiene are low.

Several studies already support the idea of recycling more thoroughly the nutrients in excreta. For instance, the Ministry of Agriculture and Forestry in Finland studied the hygienic quality of sludge from different treatment plants in 2002 in a research project called Sewage Sludge and Sludge Products for Agricultural Use - a Study on Hygienic Quality. [5] They used several indicator bacteria, among others Salmonella and Escherichia coli. Both types of pathogens were found in all the raw sludge samples taken from 22 different treatment plants. However, after certain treatment, for instance in-vessel composting, salmonella was not found. [5] In addition, Heinonen-Tanski et al studied the outdoor cucumber cultivation fertilized with separated urine. Commercial fertilizers were used as a control and the results showed that there were no coliforms present in the cucumbers, though the urine used had not been preserved before utilization. [6]

By using excreta, the need of artificial fertilizers is lower and negative impacts on soil, air and water is reduced. Environmental impacts created by agriculture and its side products are not only a problem of third world countries, but also of the developed nations. For instance, the Baltic Sea suffers significantly from eutrophication due to an exceedingly great nutrient load from agriculture and industry. [7]

This study concentrates on investigating the health risks originating from pathogens, by using coliform bacteria and Salmonella as indicators of the hygienic level of the fertilizer, soil, and most importantly, the food product. The comparison was to be made with the EC regulation 2073/2005 of microbiological criteria for foodstuff. [8]

\section{METHODS}

\subsection{The greenhouse experiment}

The experiment was to simulate as closely as possible the field conditions of the month of June in Finland. Daylight and temperature maximums were set to match these requirements. Barley (Hordeum vulgare var. Scarlett) and fungicide treated carrot seeds (Daucus carota var. Napoli FI) were used as model plants in the experiment, which commenced in November 2005 and ended in February 2006. 
The substrate was a mixture of unfertilised horticultural peat (Biolan), lime and sand. Two parallel treatments of both barley and carrot were used: commercial Kevätviljan Y3 -fertilizer for barley and Puutarhan kevät -fertilizer for carrot; 2 treatments for separated urine; 2 for composted human faeces, collected from private households and 2 for STS, collected from private households in municipality of Kangasala.

The amounts of fertilizers were determined based on the recommendations of the manufacturers of commercial fertilizers. The recommendation for Kevätviljan Y3 fertilizer was $50 \mathrm{~kg} / \mathrm{ha}$ and for Puutarhan kevät -fertilizer $800 \mathrm{~kg} / \mathrm{ha}$. The nitrogen content was used as a determining factor in calculations for other fertilizers. The amounts of fertilizers and water added based on per hectare calculations are shown in Tables 1 and 2 . The actual growth rates were of sizes $\left(\mathrm{W}^{*} \mathrm{~L} * \mathrm{H}\right) 0.26 * 0.76 * 0.25 \mathrm{~m}$.

Table 1. Fertilizer type and amount and water added to barley.

\begin{tabular}{c|c|c}
\hline \multicolumn{2}{c}{ BARLEY Hordeum vuigare var. Scarlett } \\
\hline Fertilizer & Amount/ha & Water Added/ha \\
\hline Kevätviljan Y3 & $250 \mathrm{~kg}$ & 1145831 \\
\hline Composted Faeces & $8771 \mathrm{~kg}$ & 1145831 \\
\hline Separated Urine & $4875 \mathrm{~kg}$ & up to 1145831 \\
\hline Septic Tank Sludge & 1145831 & None \\
\hline
\end{tabular}

Table 2. Fertilizer type and amount and water added to carrots.

\begin{tabular}{c|c|c}
\hline \multicolumn{3}{c}{ CARROT Daucus carota var. Napoli Fl } \\
\hline Fertilizer & Amount/ha & Water Added/ha \\
\hline Puutarhan kevät & $400 \mathrm{~kg}$ & 1145831 \\
\hline Composted Faeces & $5615 \mathrm{~kg}$ & 1145831 \\
\hline Separated Urine & $3125 \mathrm{~kg}$ & up to 1145831 \\
\hline Septic Tank Sludge & 729161 & 416671 \\
\hline
\end{tabular}




\subsection{Coliform detection}

Coliforms were analysed by a modified method of standard SFS 3950 and SFS 4447, according to instructions given by the chromogenic Compact Dry CF plates (manufacturer HyServe/Germany; supplier VWR Finland), which were used for the quantitative detection of coliform bacteria. The plates were chosen due to their simplicity and rapid results. The standard SFS 4447 is used in water sampling, but is also recommended for use in sludge sampling and in cases where samples contain a great deal of sediment. The dilutions were made based on the SFS 4447 according to the dilution water of SFS 3950. [9] The samples were taken three times from the soil and at the experiment's end, once from foodstuff, i.e. carrots and barley grains.

\subsection{Salmonella detection}

Salmonella was detected according to instructions provided for the Compact SL plates (HyServe/Germany), which were used for the qualitative detection of salmonella. The plates were chosen because of their simplicity and rapidity. Salmonella was first analysed from the various fertilizers, i.e. urine, STS, composted faeces, and a blank substrate, which was a mixture of peat, sand and lime. Later, samples from the soil mixture ingredients (i.e. peat and sand) and the seeds of barley and carrots were examined.

\section{RESULTS AND DISCUSSION}

\subsection{The crop yield}

The crop yield of carrots was best in substrate fertilized with the commercial fertilizer as can be seen from Figure 1.
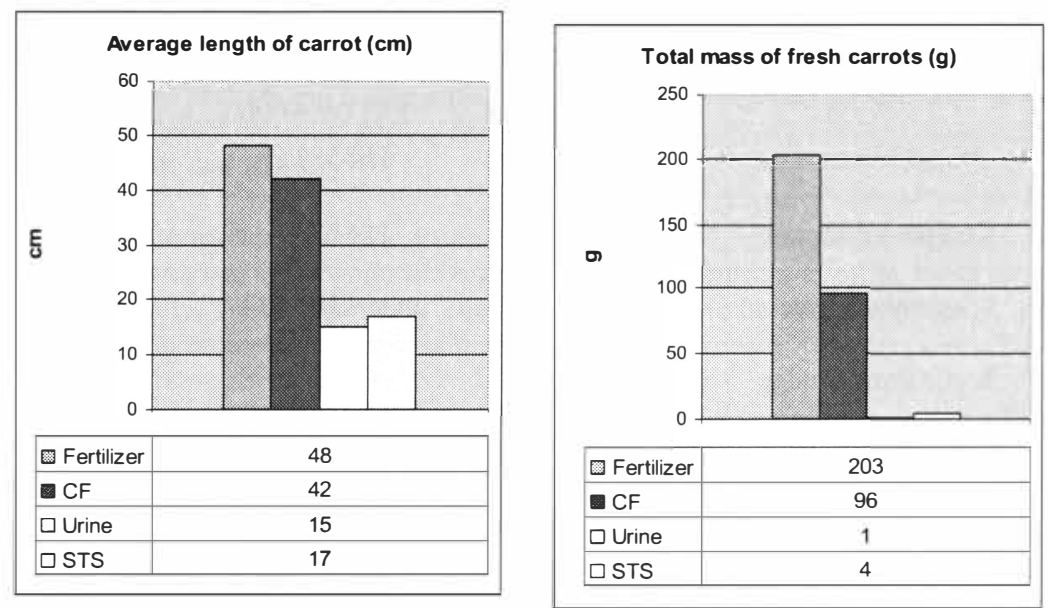

Figure 7. Physical features of carrots. 
The second best yield was from the use of composted faeces, with urine and STS fertilized substrates yielding the smallest crops. The best barley crop yield was also grown in the substrate of commercial fertilizer as indicated in Figure 2.
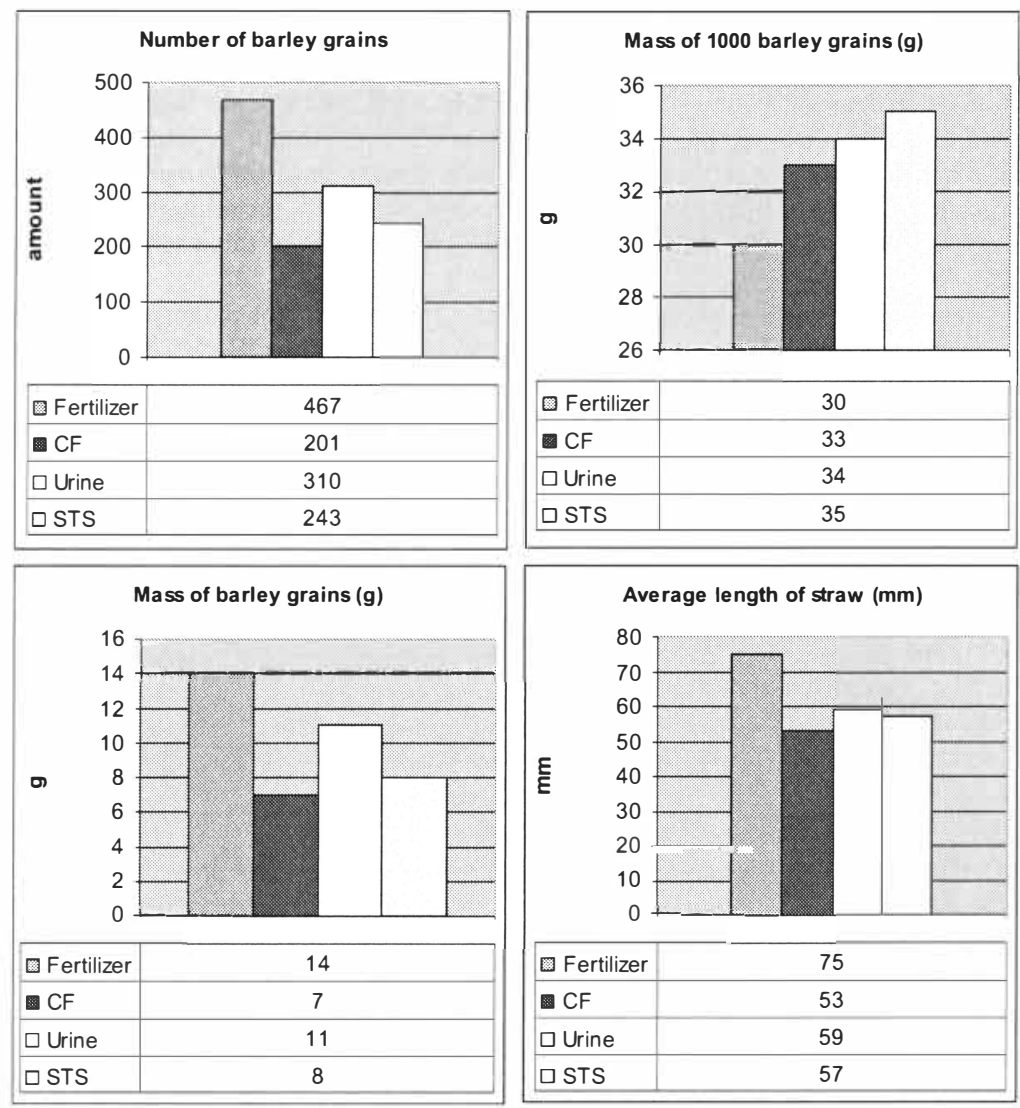

Figure 8. Physical features of barley.

\subsection{Occurrence of Salmonella and coliform bacteria}

There was no Salmonella spp. present in any of the samples analysed.

The results from the coliform bacteria detection are presented in Figures 3 and 4 as colony forming units (cfu) per 1 gram for each crate in order to compare the results with the EC regulation of microbiological criteria for foodstuff.

The control substrates were those treated with commercial fertilizers. With both barley and carrot, commercial fertilizers' showed the second greatest amounts of coliform bacteria almost consistently during the overall research. One reason might be that fields normally 
contain a small amount of coliform bacteria, which originate for instance from birds and warm-blooded animals..

Some divergence between results was noted, however, the reasons for this can be rather easily explained. The amount of coliform bacteria at the start of the study was clearly highest in substrates fertilized with septic tank sludge, which was anticipated. The urine substrates were the cleanest in terms of coliform bacteria. In the substrate of barley, using urine II, contamination most likely took place, since the level of bacteria was already high compared to the duplicate and the carrot crates fertilized with urine. In addition to contamination, another reason for differences can be due to deficient homogenisation of the sample, resulting in varying amounts of bacteria in the different duplicates. In general, incomplete mixing of excreta in the substrate causes differences in the amount of bacteria in the same sample.

The most important goal of this study was to determine whether or not pathogens transfer from fertilizer to the end product, in this case, carrots and barley grains. Barley grains from substrates' urine I and composted faeces I were completely free of coliform bacteria, and all the other barley substrates were almost completely free.

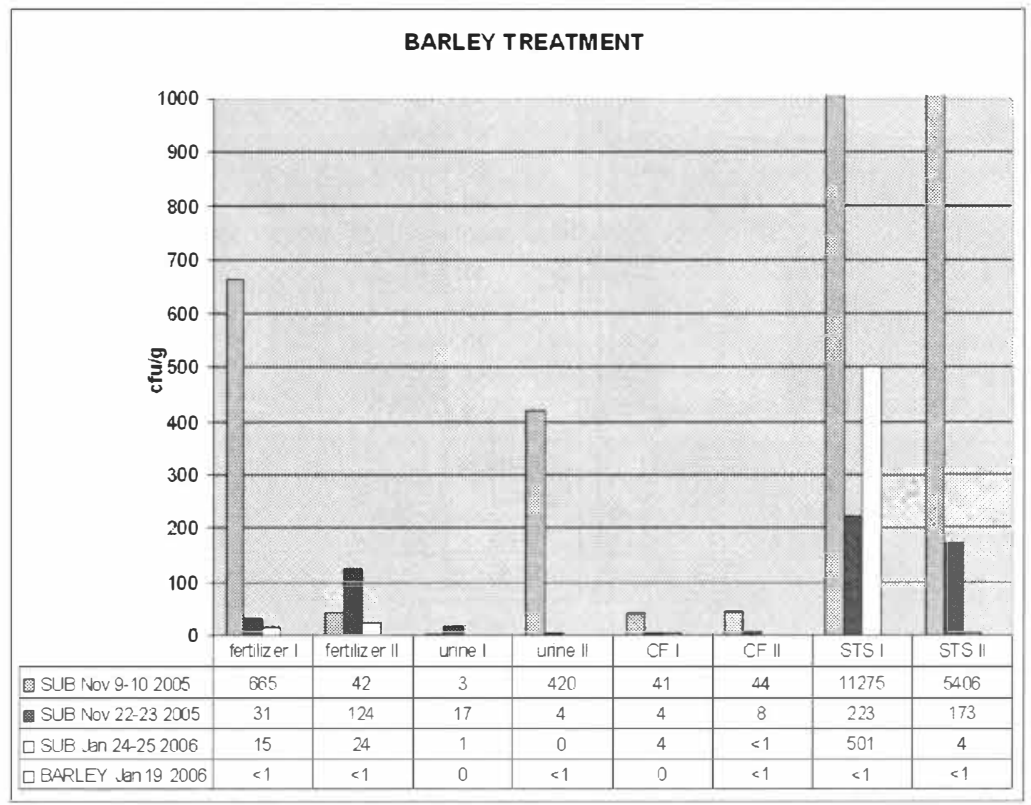

Figure 9. Coliform bacteria in the barley substrates and barley grains.

STS treated carrot samples contained high amounts of coliform bacteria. The amount of coliforms urine treatments was also over $200 \mathrm{cfu} / \mathrm{g}$. This can be explained by the pretreatment of carrot samples before analysis. It was necessary to peel the carrots in order to find out whether or not the coliform bacteria had survived. Due to the small size of urine and STS treated carrots, however, it was impossible to peel them properly. 


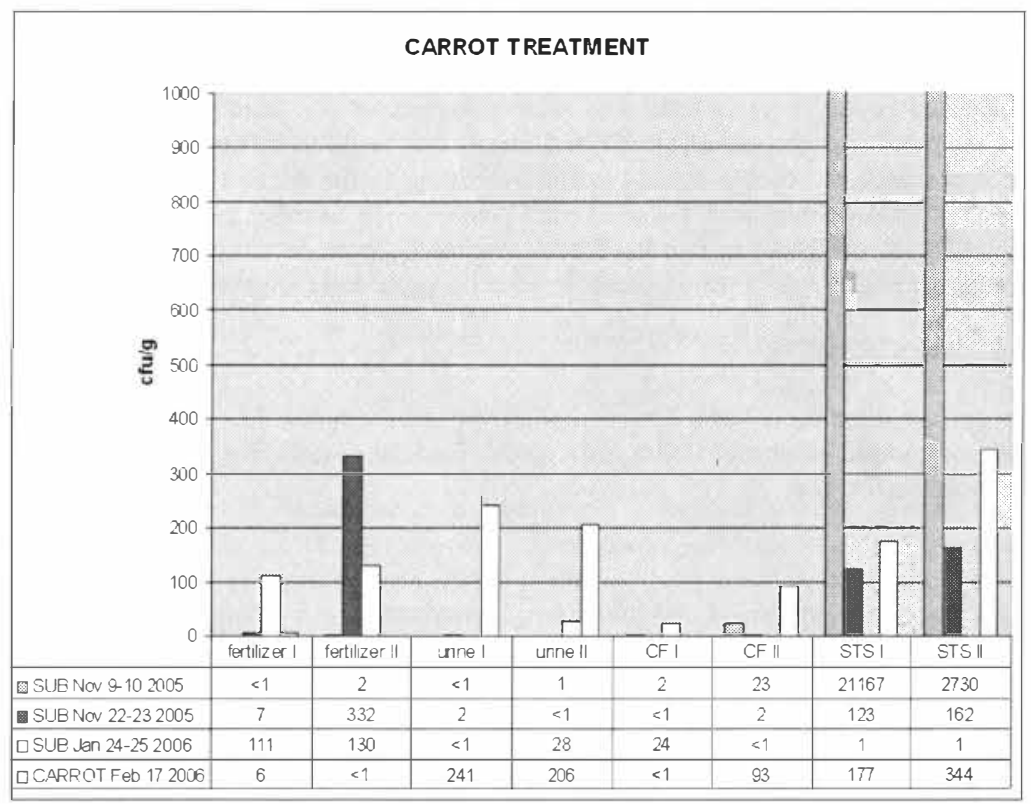

Figure 10. Coliform bacteria in the carrot substrates and carrots.

\section{CONCLUSIONS}

The results of this study indicate that human excreta compost could be used as fertilizer without it posing a significant pathogen risk for the users or consumers of the foodstuffs produced. Preliminary results from our recent studies support this finding and show that also urine is a safe fertilizer for many crops (Viskari et al. unpublished data). Urine has to be added, however, in three-four consecutive times during the initial phase of cultivation in order to achieve the best yield.

No Salmonella was found from the fertilizer products. Coliform bacteria were found in all fertilizers and the amount was highest in STS, which was expected. The decrease in coliform bacteria amounts in growth substrate during the first two weeks of the experiment was remarkable indicating a clear decrease in the pathogen risk. After two weeks the amounts in growth substrate were also in all treatments significantly lower than is allowed for fertilizer products in Finland [10].

The study for barley grains indicated that the amount of coliform bacteria was well under the satisfactory limit of $100 \mathrm{cfu} / \mathrm{g}$, with all grains resulting in less than $1 \mathrm{cfu} / \mathrm{g}$. Similarly, the barley crop yield did not greatly vary depending upon the type of fertilizer. The conclusion of this study then, is that composted human excreta used as a barley fertilizer does not pose any significant risks to human health.

The amount of coliform bacteria in the carrots tested using commercial fertilizer and composted faeces, stayed below the limit of $100 \mathrm{cfu} / \mathrm{g}$. In the case of urine and septic tank 
sludge treated substrates, the amounts exceeded a satisfactory limit, but were nevertheless still within in the acceptable limit. This latter result however, is due to the small size of the carrots, which inhibited proper peeling and thus were exposed to soil contamination. This study therefore indicates that the use of composted faeces and urine as a fertilizer for carrots does not pose any significant risk to human health according to the studied indicators. The study leaves, however, some open questions, like the possible risk of other pathogens: enterococci, clostridia and viruses. These in fact have been studied in more detail and preliminary results indicate that the health risk is almost nonexistent with urine and composted faeces.

\section{ACKNOWLEDGEMENTS}

This project was done for TAMK University of Applied Sciences. The authors would like to thank all the people working within this study. Special thanks for Sisli Piisilä and Ari Laukkanen for their work.

\section{REFERENCES}

[1] HEINONEN-TANSKI H., VAN WIJK-SIJBESMA C. Human excreta for plant production [online]. Bioresource Technology 96 (2005) 403-411 [cited 3.5.2006]. Available from World Wide Web: http://www.sciencedirect.com

[2] WECKMAN, ANJA. Ravinteet käymälästä peltoon [online]. Luopioinen: 16.7.2005 [cited 10.2.2007]. Available from World Wide Web: http://www.huussi.net/tietoa/pdf/Anja_Weckman.pdf

[3] WECKMAN, ANJA. Ihmisen ulosteet lannoitteina. Työtehoseuran monisteita 1/2000. Helsinki: Työtehoseura, 2000. ISBN 951-788-300-5.

[4] WORLD HEALTH ORGANIZATION. Guidelines for the safe use of wastewater, excreta and greywater, Volume 4: Excreta and greywater use in agriculture. World Health Organization, 2006. ISBN 92-4-154685-9.

[5] VUORINEN ARJA (ed.) et al. Sewage sludge and sludge products for agricultural use - a study on hygienic quality. Maa- ja metsätalousministeriö, LIVAKE-2001-2002. Helsinki: 2003. ISBN 952-453-113-5.

[6] HEINONEN-TANSKI, HELVI et al. Pure human urine is a good fertiliser for cucumbers [online]. Bioresource Technology 98 (2006) 214-217 [cited 15.2.2007]. Available from World Wide Web: http://www.sciencedirect.com

[7] BALTIC SEA PORTAL. Eutrophication of the Baltic Sea [online]. Finnish Marine Research Institute, 3.4.2007 [cited 12.2.2007]. Available from World Wide Web: http://www.itameriportaali.fi/en/tietoa/artikkelit/ihminen/en_GB/rehevoityminen_itame ri/

[8] COMMISSION REGULATION 2073/2005. Microbiological criteria of foodstuff [online]. Brussels: European Commission, 15.11.2005 [cited 11.2.2007]. Available from World Wide Web: http:/eurlex.europa.eu/LexUriServ/site/en/oj/2005/1_338/1_33820051222en00010026.pdf

[9] SUOMEN STANDARDISOIMISLIITTO. Mikrobiologiset vesitutkimusmenetelmät 2003. SFS-käsikirja 94. 3. ed. Helsinki: Kyriiri Oy, 2003. ISBN 952-5420-15-9.

[10] MINISTRY OF AGRICULTURE AND FORESTRY. 2007.Ministry of Agriculture and Forestry decree on fertilizer products. 12/07. [cited 30.9.2007]. Available from World Wide Web: www.finlex.fi (In Finnish) 